\title{
Dealing with Society's Secular Self-Understanding: A Reflexive Practice
}

\author{
With Marten van der Meulen, Erin Wilson and Anita Zijdemans
}

I am not a person of faith. And I have wondered whether or not it is hypocritical to take on a role in an event based on a Christian narrative, when I would be unwilling to participate in an Islamic show.

quote from a singer who played one of the main characters in The Passion, March 2018

(from personal conversation with $\mathrm{MK}$ )

In societies as volatile and fluid as those of late-modernity, norms and values are constantly subject to challenge. ${ }^{1}$ Whilst central institutions are rapidly losing their authority and power, these norms and values are being (re-)negotiated in new ways. As a consequence, the self-understanding of contemporary nations - how "we" would describe "our" society/culture/way of life - is continuously being re-shaped and re-calibrated. While individuals can reflect upon their own feelings, reactions and motives (or examine these in the consulting room of a therapist) before adjusting their behaviour or views accordingly,

1 This chapter is an updated and revised version of an article previously published as Mirella Klomp, Marten van der Meulen, Erin Wilson and Anita Zijdemans, "The Passion as Public Reflexivity: How the Dutch in a Ritual-musical Event Reflect on Religious and Moral Discussions in Society", Journal of Religion in Europe 11 (2018), 195-221. DOI: 10.1163/18748929 -01102007. The different authors' contributions to this chapter are as follows: I revised the original article for the purpose of publication in this book. The 'Background'-section was largely written by Erin Wilson. In the section 'The Passion as Public Reflexivity', the subsection 'The image of Jesus' is based on a research report written by Anita Zijdemans on the basis of the ethnographic data that she collected during fieldwork in Enschede in 2015. The subsections 'Jesus in an orange jumpsuit' and 'The morality of the actors' are based on online ethnographic fieldwork, with data collected and analysed by Marten van der Meulen and myself. 
societies examine themselves in and through the public sphere. According to anthropologist Victor Turner, plural reflexivity is public reflexivity, which means that public events offer a way for societies to portray themselves, understand themselves and then act upon themselves. ${ }^{2}$ This raises the question of whether a televised Christian event such as The Passion reveals anything about the 'secular' self-understanding of the Dutch. How do the Dutch look at their national identity when it comes to religion/secularity and morality, and what processes of deep examination and, perhaps, transformation does this evoke? Our inquiry in this chapter can be encapsulated in the following central question: how does a public event based on a Christian narrative engender public reflexivity around contemporary religious and moral debates?

This question has become particularly pressing as nominally secular and liberal politicians have in recent years started to dally conspicuously with Christian culture, narratives and symbols, reframing all kinds of secular values as part of what they often eagerly call 'the Judeo-Christian culture.. ${ }^{3}$ Their usage of Christian religion in their nationalist discourses is not neutral: it takes place in a climate of religious polarisation and rising Islamophobia. ${ }^{4}$ In fact, in Dutch 'secular' culture an appreciation for 'Judeo-Christian culture' often

2 Victor Turner, "Frame, Flow and Reflection", 465.

3 Ernst van den Hemel, "The Dutch War on Easter. Secular Passion for Religious Culture \& National Rituals", Yearbook for Ritual and Liturgical Studies 33 (2017), 1-19, here 1-2. Van den Hemel states, in his article, that he has observed "the outlines of nationalist discourse that combines secular and religious dimensions in new and influential manners. Secular political discourse increasingly embraces religion, making it an object of policy and intervention in the process". Van den Hemel, "The Dutch War on Easter", 3.

4 Academic research shows that in the most secularised countries religious polarisation is stronger. See Egbert Ribberink, Peter Achterberg and Dick Houtman, "Religious polarization: contesting religion in secularized Western European countries", Journal of Contemporary Religion 33, no. 2 (2018), 209-227. DOI: 10.1080/13537903.2018.1469262. The results of an online poll of people's attitudes regarding different religions held by research company YouGov, show that Western respondents in particular had less favourable views of Islam than they did of other religions (both in countries with a Christian majority and in countries that used to have a Christian majority). See Rogers de Waal, Joel, "Western/MENA attitudes to religion portray a lack of faith in common values", YouGov, February 3, 2019. https://yougov.co.uk/topics/international/articles-reports/2019/o2/o3/westernmena -attitudes-religion-portray-lack-faith-. Last accessed May 10, 2020. Regardless of whether the Netherlands is classified as secularised country, Islamophobia in the Netherlands has increased since the year 200o, according to sociologist of religion Sipco Vellenga in his article "Anti-Semitism and Islamophobia in the Netherlands: concepts, developments, and backdrops", Journal of Contemporary Religion 33, no. 2 (2018), 175-192. DOI: 10.108o/13537903.2018 .1469257 . 
goes hand in hand with a dislike for 'Islam'.5 Media (whether printed, broadcast, or online) do not play a neutral role here: they have the power to allow some voices to be heard and to silence others, to cover and frame some incidents and ignore others. ${ }^{6}$ This chapter will show that media have a strong voice in current societal debates, including those about religion, and that they thus have an influence on collective communication around the secular selfunderstanding of a society more generally.

The term 'public reflexivity' was coined by Victor Turner as part of his argument that all societies have their own public meta-social rites, which are "performed at crucial points in the turning year, or on occasions of collective crisis when a whole society faces a major change". ${ }^{7}$ In this chapter we employ Tuner's theory to try to understand the societal and public dynamics surrounding The Passion in a Dutch religious landscape currently subject to processes of transformation. After elaborating on Turner's theory, we sketch the background to current public debates surrounding religion and post-secularity in Europe and the Netherlands. We then focus in on three particular themes that we encountered during our empirical research on The Passion: the particular characteristics of Jesus that the organizers sought to convey, the complex meaning-making which took place around the design decision to use the orange costumes (an example which we described in Chapter 5 , but which we here discuss from a different viewpoint), and the suitability of the actors playing Jesus and Barabbas to perform in The Passion in relation to their past 'immoral' behaviour. We will use our analysis of these topics in order to demonstrate how performances like The Passion offer spaces in which the Dutch can reflect publicly on important identity issues, such as the role of Christian heritage and the visibility of Muslims in a supposedly secular age.

5 Van den Hemel, "The Dutch War on Easter", 10.

6 In her PhD thesis on the representation of Muslims on Dutch television in the past sixty years, Andrea Meuzelaar reveals how the television coverage of Islam and Muslims "has resulted in a rigid iconography that has made Islam instantly recognizable, but has also reduced Islam to a handful of emblematic images that now carry connotations far beyond their initial significance". Andrea Meuzelaar, "Seeing through the archival prism. A history of the representation of Muslims on Dutch television" (PhD diss., University of Amsterdam (Faculty of Humanities), 2014), 134. She concludes that in the years 2000-2010, "television coverage of Dutch Muslims became very much fixated on the issues of fundamentalism and terrorism in the Netherlands, the radicalisation of young Muslims, radical imams, the position of Muslim women, headscarves and veiling". Meuzelaar, "Seeing through the archival prism", 119.

7 Turner, “Frame, Flow and Reflection", 466. 


\section{Exploring Uncertainties around National Identity}

As far back as 1979, Turner observed that there is a close relationship between drama and reflection: a group communicates to itself about itself in various ways, verbally (through speech) and non-verbally (through "gestures, music, dancing, graphic representation, painting, sculpture, and the fashioning of symbolic objects"). ${ }^{8}$ Ritual and drama, in Turner's view, are forms of plural reflexivity, and since drama is a public event, plural reflexivity often means public reflexivity. Drawing on folklorist Arnold van Gennep's distinction between rituals performed at moments of life-crisis and rituals performed at crucial points in the turning of the year or during collective crises, Turner focuses on the latter: rituals which are public in character, which are performed for collectivities. This latter type of rite enacts aspects of 'ritual or status reversal', but also reveals the constant presence of a meta-language "that is, codes or presentation and expression which enable participants and spectators to realise just how far they have fallen short of or transgressed their own ideal standards, or even, in some kinds of ritual, to call those very ideals into question under conditions of sharp social change". ${ }^{9}$

These public meta-social rites, as Turner calls them, are often performed in village or town squares where they are visible to everyone, and they use every day spaces as their stages so as to 'consecrate' these spaces for the duration of a liminal and 'transitory' time-period. According to Turner, it could, slightly simplistically, be suggested that "for every major social formation there is a dominant mode of public liminality", and that there is therefore some kind of relationship between social processes and performative genres. ${ }^{10}$ When engaged in processes of self-reflection, a society sets up "a frame within which images and symbols of what has been sectioned off can be scrutinised, assessed, and, if need be, remodelled and rearranged"."11 According to Turner, what is put inside the frame is often considered to be sacred, and this is thereby separated from that which is 'profane', 'secular', or 'mundane'. Rituals have a scenario/score, and they mostly contain festive, joyful, and playful episodes and incidents: they are serious and entertaining, solemn and ludic at the same time. ${ }^{12}$ In stage drama - which is identified by Turner as a major reflective genre - authorship of scenarios is attributed to individuals. Nevertheless, stage plays are as much public as private modes of performance: they involve "ac-

\footnotetext{
8 Turner, "Frame, Flow and Reflection", 465.

9 Turner, "Frame, Flow and Reflection", 467.

10 Turner, "Frame, Flow and Reflection", 468.

11 Turner, "Frame, Flow and Reflection", 468.

12 See Chapter 5.
} 
tors, audience, producers, stagehands, often musicians and dancers, and, most of all, their plots and messages are communicated by various written and oral networks to a general public which varies in span and composition from society to society and from epoch to epoch". ${ }^{13}$ In stage drama, descriptive narrative and reflexive commentary are interwoven with one another. This kind of reflexivity is not only engaged in by the performers, but also by the author and the public. The author reflects, whereas the actors flow, ${ }^{14}$ and the audience is moved. ${ }^{15}$

Another conceptualisation of the sacred has been offered by Gordon Lynch. Like Turner before him, Lynch draws on Durkheim, in particular on his emphasis on the sacred and processes of sacralisation in daily life. In Lynch's view, the sacred consists of those things and events that are of ultimate significance to people. In society, there are sacred forms which serve as "specific instantiations of the sacred" in which "symbol, emotion, normative claims, ritual practice, and social collective" intersect. ${ }^{16}$ These sacred forms may be religious, but can also be secular, without any reference to transcendence. Lynch thus attempts to disentangle the concepts of the 'religious' and the 'sacred' that have often been confounded in social theory.

In their 2014 study of contemporary liturgical ritual, Marcel Barnard, Johan Cilliers, and Cas Wepener build upon the liminal theories of van Gennep and Turner, suggesting that:

[the renewal of liturgical ritual] moves between the established churches and their traditional liturgical forms, on the one hand, and less defined spaces, times and groups on the other hand. [...] Late-modern culture is also characterized by notions such as transformations, transgression, transcultural and border crossing. However, instability still - and ever more so - evokes the opposite notion and desired condition of stability, perhaps a consequence of a lack of late-modern cultural awareness. ${ }^{17}$

When brought together with these reflections, Lynch's argument becomes even more compelling: the sacred moves and is also to be found outside of the religious domain, both in liturgical rituals and in a range of other forms:

13 Turner, "Frame, Flow and Reflection", 486.

14 I.e., their "action follows action according to an inner logic which seems to need no conscious intervention on [their] part, [...] there is little distinction between self and environment, between stimulus and response, or between past, present and future". Quote from Turner, "Frame, Flow and Reflection", 490.

15 Turner, "Frame, Flow and Reflection", 490.

16 Lynch, The Sacred in the Modern World, 9 and 26, respectively.

17 Barnard, Cilliers and Wepener, Worship in the Network Culture, 65. 
it cannot be fenced in by religion. The Passion may therefore be considered to be an event that has become sacred not just because but also in spite of its underlying Christian religious narrative.

The Passion, seen as a contemporary form of longer-standing annual traditions of Passion performance, is a public ritual, performed for collectivities, as described by Turner. In the twenty-first century, such public rituals take shape in a culture that is influenced by mediatisation, by leisure time characterised by increasing eventfulness and hyperfestivity, by ludification, and by the aforementioned dynamics of religious polarisation. ${ }^{18}$ These developments do not simply pass us by without also having an effect both on religion and on religious practices. Thus, when translating Turner's theory for the circumstances of late-modern Dutch culture, we might say that The Passion points to what might be considered a dominant mode of public liminality in this society. ${ }^{19}$ The Passion demonstrates many examples of public reflexivity, not only in the performance itself, but also in the public domain, for example on television or on Twitter. The Passion can be seen as a meta-social ritual which Dutch society uses in order to explore its own uncertainties around national identity. In the twenty-first century, these uncertainties, among other things, relate to the question of the supposedly secular nature of the Dutch public sphere, and the rising visibility of religion, particularly Islam. The Passion can also be seen as a sacred form, since it takes place at the intersection between symbols, emotions, normative claims, ritual practices, and the social collective. Before we

18 On mediatisation, see Stig Hjarvard, The Mediatization of Culture and Society (London: Routledge, 2013); Stig Hjarvard and Mia Lövenheim, eds., Mediatization and Religion: Nordic Perspectives (Göteborg: Nordicom, 2012). On hyperfestivity, see Greg Richards, Leisure in the Network Society: From Pseudo-events to Hyperfestivity? (Tilburg: Tilburg University, 2010), esp. 13; cf. Paul Post, "Panorama der Ritual Studies: Trends und Themen der aktuellen Ritual Studies", Archiv für Liturgiewissenschaft (2013 [2015]), 139-181, esp. 164 where Post defines leisure culture as one of the fields where the sacred is found. On ludification, see Raessens, "The Ludification of Culture", 91-114. On polarisation and Islamophobia, see Ribberink, Achterberg, and Houtman, "Religious polarization"; Van den Hemel, "The Dutch War on Easter"; Vellenga, "Anti-Semitism and Islamophobia"; Meuzelaar, "Seeing through the archival prism".

19 Turner himself would have defined these events as 'liminoid'. This term indicates that modern events are, according to Turner, quite different from traditional ritual practices in pre-modern societies. He was, therefore, hesitant to use his theory of liminality and ritual in relation to modern societies. He looked instead for modern functional equivalents, which he called liminoid. This distinction has been criticised by others: the correspondence between pre-modern and modern ritual, especially when it comes to large public events, seems too great to warrant a different term. Sharon Rowe, for example, has argued that modern sporting events can rightly be described as liminal. See Sharon Rowe, "Modern Sports: Liminal Ritual or Liminoid Leisure", in Victor Turner and Contemporary Cultural Performance, ed. Graham St. John (New York \& Oxford: Berghahn Books, 2008), 127-148. We concur with her. 
dive deeper into The Passion itself, we want to first sketch some of the broader context regarding the role of public religion. In particular, recent debates surrounding post-secularity both in Europe and the Netherlands are relevant here.

\section{Background: From Secular to Post-secular in European Public Life?}

The secular character of contemporary European (and Dutch) society has been subject to wide and varied debate. This debate warrants some brief discussion in order to sketch the backdrop against which The Passion takes place and in order to bring the potentially fruitful contribution of Turner to bear on this debate.

Over the course of the last decades, a number of incidents have raised important questions regarding the validity of common assumptions regarding the secularisation of Europe. These incidents include debates over whether to include reference to a common Christian heritage in the European Constitution; unease over Turkey's potential membership of the EU; debates about the presence of religious symbols in the public sphere, in which Christian symbols are often classified as 'cultural heritage' whilst headscarves, turbans, and other objects are classified as 'religious'; rising concerns over the growing presence of 'radical Islam' in Europe; the refugee crisis, in which questions about the religious identity of refugees have become entangled with debates regarding security, the appropriate humanitarian response, and European social cohesion; and the so-called 'burkini ban' in France that has provoked major controversy in Europe and around the world. ${ }^{20}$ These incidents all suggest that Europe's secular character cannot simply be taken for granted. ${ }^{21}$

$20 \quad$ On the classification of 'cultural' and 'religious', see Lori Beaman, "Battles over Symbols: The 'Religion' of the Minority Versus the 'Culture' of the Majority", Journal of Law and Religion 28, no. 1 (2013), 141-157. On the refugee crisis, see Erin Wilson and Luca Mavelli, "The Refugee Crisis and Religion: Beyond Conceptual and Physical Boundaries", in The Refugee Crisis and Religion: Secularity, Security and Hospitality in Question, eds. Luca Mavelli and Erin Wilson (London: Rowman and Littlefield International, 2017), 1-22; The Economist. "Diverse, desperate migrants have divided European Christians", http://www.economist .com/blogs/erasmus/2015/o9/migrants-christianity-and-europe. September 6, 2015. Last accessed May 10, 2020; EU Observer. "EU states favour Christian migrants from the Middle East", https://euobserver.com/justice/129938. August 21, 2015. Last accessed 1 October 2019. On the 'burkini ban', see The Guardian, "France's Burkini Ban Exposes the Hypocrisy of the Secularist State", August 24, 2016. https://www.theguardian.com/commentisfree/ 2016/aug/24/france-burkini-ban-secularist-equality-muslim?CMP=fb_gu. Last accessed May 10, 2020.

21 Benoît Challand, "From Hammer and Sickle to Star and Crescent: The Question of Religion for European Identity and a Political Europe”, Religion, State and Society 37, no. 1 
José Casanova has claimed that the very formation of the European Union $(\mathrm{EU})$ is rooted in Christian thought and practice. ${ }^{22}$ Although the intimate relationship between Christianity and modern European identity is contested, ${ }^{23}$ Europe's secular nature is often emphasised over its relationship to Christianity, and the dominant narrative told about Europe's historical development is the successful separation of religion from politics and law in order to establish communities of peace and tolerance. ${ }^{24}$ An emphasis on a European 'Christian cultural heritage' over and against a seemingly growing and hostile Islam is a much more recent development which intersects with broader trends towards narratives of 'good religion/bad religion' in global politics. ${ }^{25}$

As part of the renewed interest in religion in European public life, the concept of the 'post-secular' has emerged as an attempt to make sense of this renewed presence. Erin Wilson and Manfred Steger have argued that the postsecular has been utilised both as a description of and as a response to the

(2009), 65-80; Elizabeth Shakman Hurd, The Politics of Secularism in International Relations (Princeton: Princeton University Press, 2008); Lucian N. Leustean and John T. S. Madeley, "Religion, Politics and Law in the European Union: An Introduction", Religion, State and Society 37, no. 1 (2009): 3-18; Francois Foret, "Religion: A Solution or a Problem for the Legitimisation of the European Union?" Religion, State and Society 37, no. 1 (2009), 37-50, here 38 .

22 José Casanova, "Religion, European Secular Identities and European Integration", in Religion in an Expanding Europe, eds. Timothy A. Byrnes and Peter J. Katzenstein (Cambridge: Cambridge University Press, 2006), 65-92, here 66.

23 José Casanova, "The Secular and Secularisms", Social Research 76, no. 4 (2009): 10491066, here 1058-1059; Leustean and Madeley, "Religion, Politics and Law", 4. Jeffers Engelhardt, for example, speaks about the historical imagery of a Christian Europe (Jeffers Engelhardt, "Arvo Pärt and the Idea of a Christian Europe. The Musical Effects and Affects of Post-Ideological Religion", in Jeffers Engelhardt and Philip Bohlman, Resounding Transcendence. Traditions in Music, Religion, and Ritual (Oxford: Oxford University Press, 2016), 215-231), whereas an author like Tom Holland claims that Christianity is intimately related to Western identity (Tom Holland, Dominion. The Making of the Western Mind (London: Little Brown, 2019)).

24 Jean-Paul Willaime, "European Integration, Laïcité and Religion", Religion, State and Society 37 , no. 1 (2009), 23-35.

25 Beaman, "Battles over Symbols". For a detailed discussion of the 'good religion/bad religion' narrative, see Elizabeth Shakman Hurd, Beyond Religious Freedom: The New Global Politics of Religion (Princeton: Princeton University Press, 2015). Vellenga, in a recent article on anti-Semitism and Islamophobia, concludes that: "In the Netherlands, the general level of the annual numbers of recorded incidents of anti-Semitism and Islamophobia has increased since 2000 and, at the same time, there have been significant fluctuations in the numbers of notified incidents per year. The fluctuations correlate to outbursts of violence in the Middle East and to acts of violence committed in the name of Islam in the West. The increase of anti-Semitism and Islamophobia relates to real, symbolic, and social threats experienced in the context of Dutch multi-ethnic society, changes in national identity, and trends in globalisation". Vellenga, "Anti-Semitism and Islamophobia", 187. 
apparently new context of public religion in which we find ourselves. ${ }^{26}$ Jürgen Habermas also uses the term in order to explain the continuing and, in some cases, revived presence of religion in secular European societies. ${ }^{27}$ Since the 1980s, and especially with the end of the Cold War and developments after $9 / 11$, it has become manifestly clear that 'religion' - variously understood, but usually framed in terms of personal belief systems, traditions, and institutions - is not dying out, contrary to the predictions of secularisation theory, but, rather, is taking on new significance in a range of alternative forms. ${ }^{28}$

The concept of the post-secular has met with significant critique, especially regarding the utility of the term as a description of the current European moment. ${ }^{29}$ Firstly, the prefix 'post' suggests that at one time Europe was 'secular' but that is has subsequently moved beyond this. ${ }^{30}$ Secondly, the emergence of the idea of 'secularism' and the 'secular' from out of Christian theology raises additional problems regarding the neutrality and universality of secularism and whether Europe has ever been 'secular' in the sense of being areligious. ${ }^{31}$ Indeed, understandings of the secular and secularisation have often rested on the assumption that secularisation is characterised by declining church attendance and declining belief in God. ${ }^{32}$ Yet, this assumes a highly Christian perhaps even a doctrinal ${ }^{33}$ - understanding of 'religion'. Indeed, in some cases,

26 Erin Wilson and Manfred Steger, "Religious Globalisms in a Post-secular Age", Globalizations 10, no. 3 (2013), 481-495, here 485-487.

27 Jürgen Habermas, "Religion in the Public Sphere", European Journal of Philosophy 14, no. 1 (2006), 1-25.

28 José Casanova, Public Religions in the Modern World (Chicago: Chicago University Press, 1994); Hurd, The Politics of Secularism; Mark Juergensmeyer, The New Cold War? Religious Nationalism Confronts the Secular State (Berkeley \& Los Angeles: University of California Press, 1994); Lucian Leustean and John Madeley, "Introduction: Religion, Politics and Law in the European Union", in Religion, Politics and Law in the European Union, eds. Lucian Leustean and John Madeley (London: Routledge, 2009), 1-16; Daniel Philpott, "The Challenge of September 11 to Secularism in International Relations", World Politics 55, no. 1 (2002), 66-95. See also Jonathan Arnold, Music and Faith. Conversations in a Post-Secular Age (Suffolk: Boydell and Brewer, 2019).

29 See, e.g., James A. Beckford, "Public Religions and the Postsecular: Critical Reflections", Journal for the Scientific Study of Religion 51, no. 1 (2012), 1-19.

30 Ahmet T. Kuru, Secularism and State Policies Towards Religion (Cambridge: Cambridge University Press, 2009).

31 Casanova, "The Secular, Secularity, Secularism", 54-74.

32 See, e.g., Steve Bruce, God Is Dead: Secularization in the West (Oxford \& Malden: Oxford University Press, 2002); Ken R. Dark, "Large-scale Religious Change and World Politics", in Religion and International Relations, ed. Ken R. Dark (London: Macmillan, 2000), 50-82.

33 This definition of religion, in which 'belief' is one of the main constituents, is often believed to have emerged out of the so-called Further Reformation and is frequently also connected to Anglo-Saxon Puritanism and German Pietism. The second reformation can 
secularisation has been defined as a decline in 'traditional Christian religiosity', not as a decline in 'religion' more generally. ${ }^{34}$ Furthermore, the categories of the 'religious' and 'secular' themselves have been demonstrated by numerous authors to be problematic. ${ }^{35}$ The rise of public non-Christian forms of religiosity, in particular Islam, in Europe in recent years has, to some extent, highlighted the way in which 'religion', and specifically 'Christianity', is not as separate from identity and politics in Europe as it was previously assumed to be.

Whether or not the idea of the 'post-secular' is considered to be an apt concept, the term nevertheless points to the contested nature of both religion and secularity in contemporary Europe. What it means to be religious (Christian/Muslim/...) and/or secular is indeed part of ongoing discussions in media, in politics, and in the personal sphere. In light of this, the popularity of events such as The Passion should be no surprise, especially not if they bring core societal topics of religion/secularity, such as the role of Christian heritage, the position of Islam in Europe, and the role of public morality to the fore.

\section{The Passion as Public Reflexivity}

Three controversial and striking issues specifically related to the topics of secularity and religiosity emerged during our ethnographic fieldwork over the course of $2015 .{ }^{36}$ Bearing Turner's theory of public reflexivity in mind, we decided to analyse interviews, photographs, and websites which referenced three particular related topics: the general character, demeanour, and appearance of

be understood as "the movement within the Reformed Church of the seventeenth (and eighteenth) century in response to the flattening of the faith and indeed to deepen and broaden the impact of the sixteenth-century Reformation. Its representatives urged with prophetic force the application of the Reformed doctrine to personal and public life as well as holiness in all areas of life". Herman Selderhuis, "The Further Reformation", in Handbook of Dutch Church History, ed. Herman Selderhuis (Bristol, CT: Vandenhoeck \& Ruprecht, 2014), 338-341, here 338.

34 See, e.g., Dick Houtman, Stef Aupers, and Paul Heelas, "Christian Religiosity and New Age Spirituality: Cross-Cultural Comparison", Journal for the Scientific Study of Religion 48, no. 1 (2009), 169-179.

35 See, e.g., Hurd, The Politics of Secularism; William T. Cavanaugh, The Myth of Religious Violence (Oxford: Oxford University Press, 20o9); Talal Asad, Formations of the Secular (Stanford: Stanford University Press, 2003), as well as the previous chapter of this book.

36 Over the course of its history, between 2011 and 2019, The Passion has shown engagement with a number of current societal and also core political topics, such as the influx of refugees, life in a multi-cultural society, loneliness, and disasters which have had a high impact on cities; see Chapter 1 for discussion of the subsequent editions of The Passion that reflected these topics. 
Jesus in The Passion; the choice to have Jesus appear before Pontius Pilate in an orange jumpsuit; the character of the actors playing Barabbas and Jesus, in particular discussions related to the actors' (immoral) pasts. In what follows, we will discuss these topics consecutively on the basis of Turner's theory, relating them to current issues and (public) debates in Dutch society. The first two issues are further enriched by some late fieldwork material gathered after 2015 .

\section{An Image of Jesus}

It was the rejection of the first promotional photos portraying the Jesus figure that drew our attention to the issue of the image and character of Jesus. When asked about the image of Jesus which they wished to convey through the event, the remarkable first response from members of the production team was always that they did not have one particular image of Jesus in mind and, instead, that the image depended on the actor portraying Jesus, whilst the event itself is meant to leave room for audience interpretation. Yet, given that they themselves select the actor to play Jesus, there seemed to be some prior conception of the image of Jesus which exerted influence upon processes of decision-making, namely that of a tall, slim, white man with a moustache, a beard and long curly hair, ${ }^{37}$ the main physical features that determine the 'classical Jesus-look'. A man, also, who is honest and open. This is a very particular and distinct image of Jesus, with roots in Western visual culture. After the initial promotional photo shoots which were taken of members of the cast for the purposes of marketing the 2015 edition, the pictures portraying Jim de Groot in the role of Jesus were rejected - an incident which is highly revealing. De Groot's body language was considered to be not open enough, and thus to be unfitting, particularly in the photos that portrayed him standing with folded arms. "Jesus should instead have an open attitude. [...] I would like to have more pictures where he stands with his arms open, with an open attitude, reaching out to people, looking up (to heaven), etcetera". ${ }^{38}$ New photos had to be taken, and during the second photoshoot (at which we were present), we observed that "openness" and also "integrity" were keywords. It was important to the organisation that Jesus looked welcoming to all people. Aside from this,

37 In 2016, the singer who played the role of the Jesus character was not slim at all, and for this reason he was presented in the media as a "contested" person. See "Omstreden Martijn Fischer klaar voor rol van Jezus in The Passion", ShowNieuws, February 22, 2016, https://www.shownieuws.nl/video/clips/2016/omstreden-martijn-fischer-klaar -voor-rol-van-jezus-passion/. Last accessed May 10, 2020.

Anon., email to MK, fieldwork 2015. 


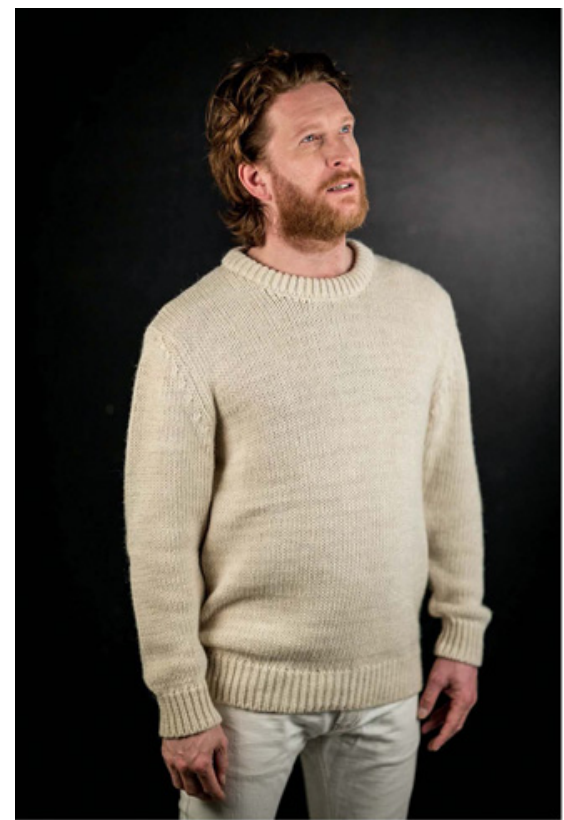

_Z6A4063@Hans-Peter van Velthoven.JPG

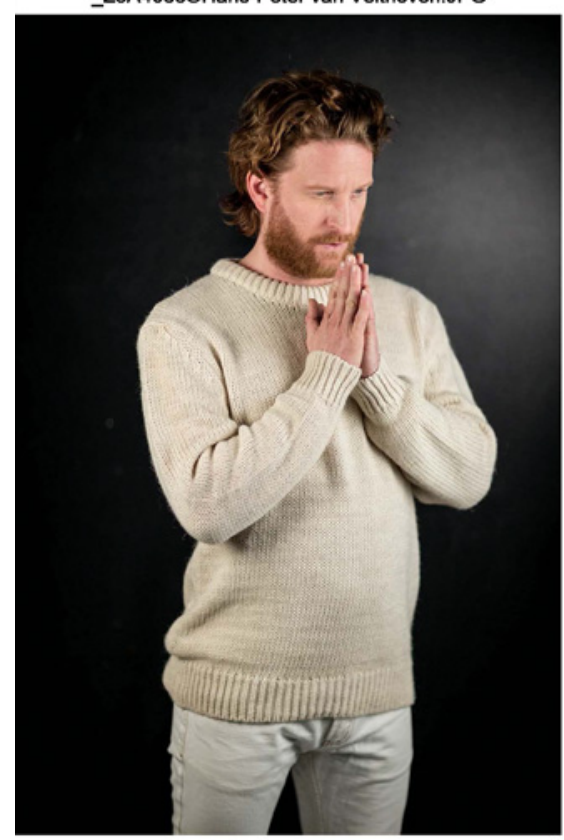

Z6A4065@Hans-Peter van Velthoven.JPG

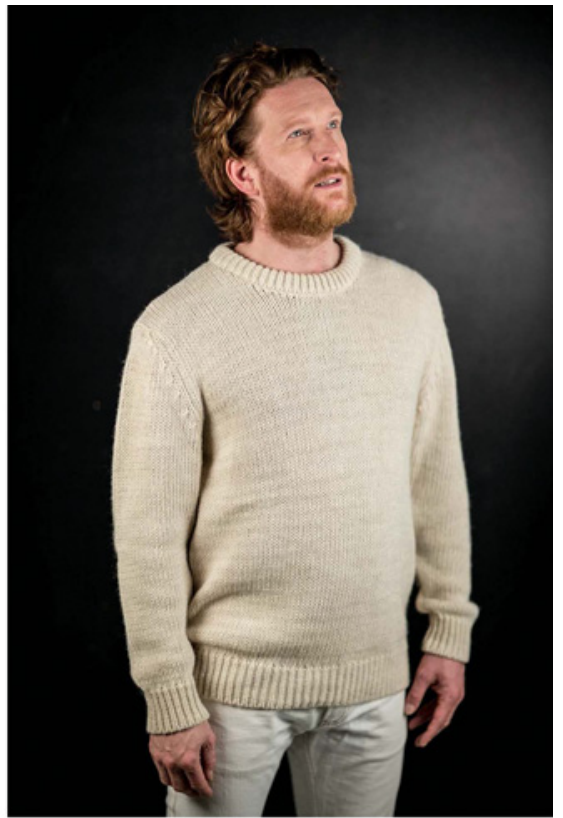

_Z6A40640Hans-Peter van Velthoven.JPG

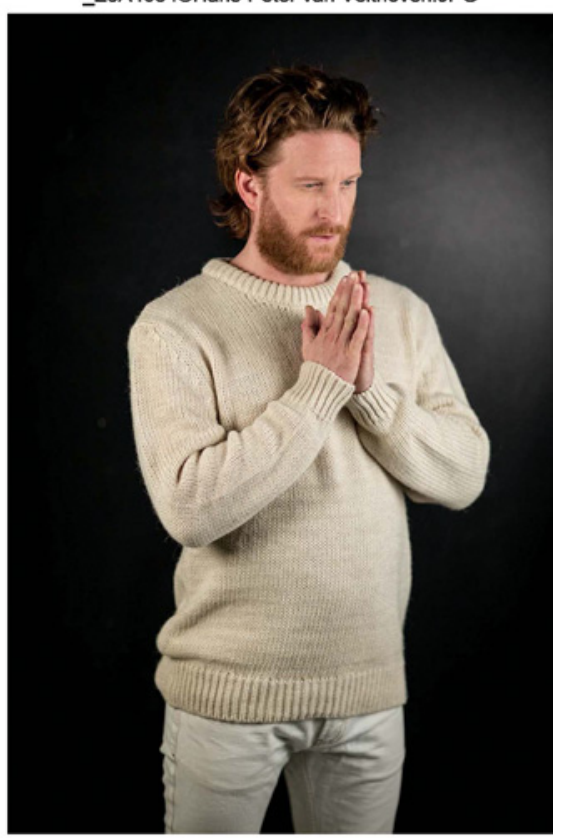

Z6A40660Hans-Peter van Velthoven.JPG

FIGURE 10 Pictures from the second photo shoot with Jesus, 2015

PHOTO: (C) HANS-PETER VAN VELTHOVEN 
it was deemed important that Jesus showed compassion and love. During the photoshoot, de Groot was told several times to make his expression softer in order to accomplish this. At the same time, several people in the production team added, in conversation with us, that openness and kindness were not enough: Jesus also needed to be strong, to be a leader, and not, as one of them put it, "a flunky". ${ }^{39}$ Several also remarked that de Groot looked like Jesus, but then quickly added that this was of course only intuitive, since 'we do not and cannot know what Jesus really looked like'. De Groot's hair and beard, in particular, were strongly associated with Jesus' appearance. This confirms that the organisers did indeed have a classical image of Jesus in their minds, which they brought with them into the production of The Passion, namely that of a white, Western (attractive?) guy. In the nine editions of The Passion which took place between 2011 and 2019, the appearance of the Jesus character rarely deviated much from this image. ${ }^{40}$ In an ethnically and culturally diverse society, the prevailing image of Jesus, with a few exceptions, generally resembles an autochthonous Dutch man. It seems that Western visual culture still influences the casting of the Jesus character in The Passion. As a result, Christianity is (again) actively linked to Dutch culture.

\section{Jesus in an Orange Jumpsuit: Islamic Terrorist or Christian Victim?}

At the point in the performance of The Passion at which Jesus is arrested, he is dressed in an orange jumpsuit, and, after the conviction, a black bag is placed over his head before he is escorted off the stage by two security guards in black uniforms. ${ }^{41}$ The orange jumpsuit and the black uniforms have been both part

39 Interview April 13, 2015 (1) conducted by Anita Zijdemans.

40 In all editions of The Passion so far, the men playing the Jesus character have had beards or, at the very least, a bit of stubble. Most editions have cast white men in the role of Jesus, and black men have only been cast for this role twice (singers Dwight Dissels and Edwin Jonker, both with Surinamese roots, in 2017 and 2019). The one man with Mediterranean looks to have his name suggested during the casting process for 2018, was rejected by one of the organising parties because he was a practising Muslim (see the second issue, elaborated below). The suggestion of having a female play the role of Jesus has been made twice, by the (female) narrator of the 2016 edition, Lenette van Dongen, and by the author of an op-ed in one of the Dutch newspapers, who encouraged the organisers to go for a less 'old-fashioned' edition of The Passion. See De Volkskrant, "Tijd voor vrouwelijke Jezus in The Passion", March 26, 2016, https://www.volkskrant.nl/nieuws-achtergrond/tijd-voor -vrouwelijke-jezus-in-the-passion bf87aodg/. Last accessed May 10, 2020. Up until the 2018 edition, this suggestion has not been taken up by the organisers.

41 Like Jesus, Barabbas too is presented to the public as a prisoner wearing an orange jumpsuit. We focus here on the presentation of Jesus because he plays a crucial role in Christianity and may, in this case, even be considered to symbolize Christianity or Christians 
of this scene and a subject of discussion, mostly on Twitter and Facebook, since the first edition of The Passion in Gouda in 2011. Yet, in 2015, the scene prompted strong(er) reactions from many viewers via social media. After previous editions of The Passion, the potential association with 'Guantanamo Bay' (the American base associated with images of Al-Qaeda and Taliban detainees wearing orange jumpsuits) had been mentioned in connection to the orange costumes (with Jesus resembling a religious terrorist to be put away), but in 2015 many people on social media saw a strong connection between these orange jumpsuits and videos that had been circulating depicting the execution of prisoners, and particularly Christian dissidents, by the Islamic State (ISIS) in Iraq and Syria.

The depiction of Jesus in an orange jumpsuit was seen by viewers as a symbol of religious persecution, particularly the persecution of Christians, and the Easter story was interpreted by some as a message about the importance of the right to freedom of religion or belief, although this was not the explicit intention of the organisers of the event. This interpretation is clearly articulated in

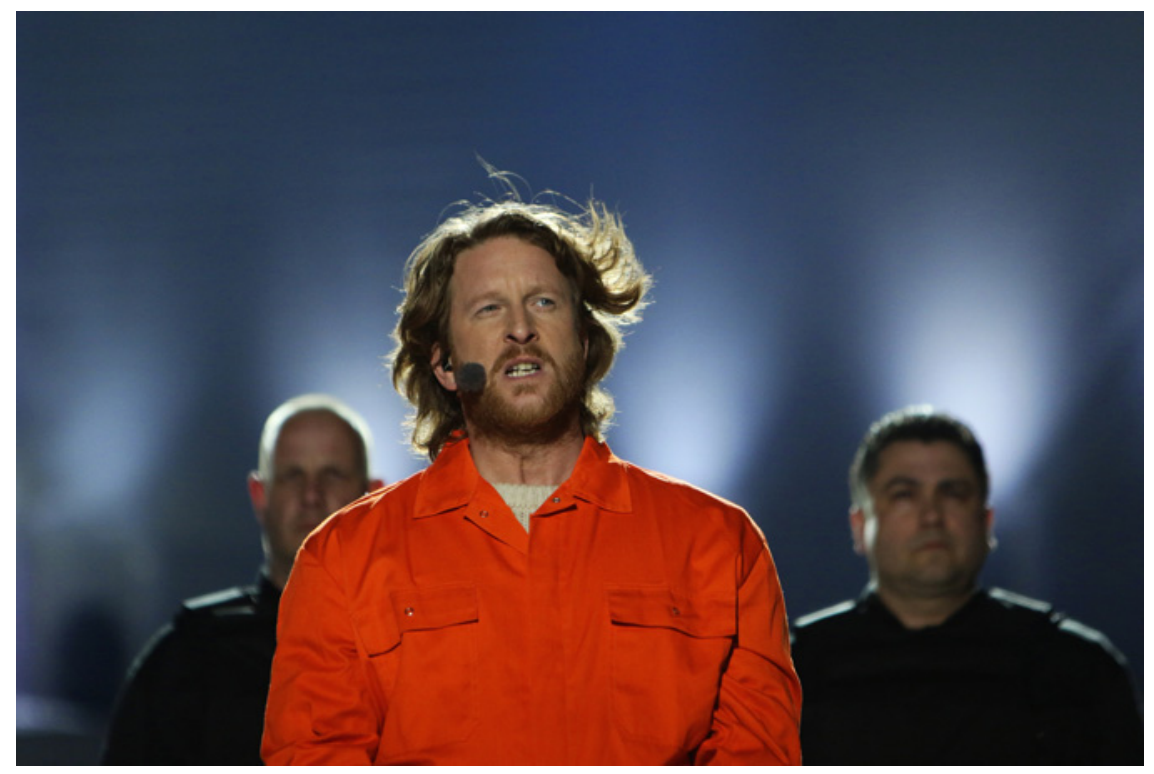

FIGURE 11

The Jesus character in an orange coverall with two soldiers after his conviction in The Passion, Enschede, 2015

PHOTO: ARIANNE RAMAKER. CEO

as a whole, as well as because of the way in which his wearing an orange coverall caused upheaval on social media. 


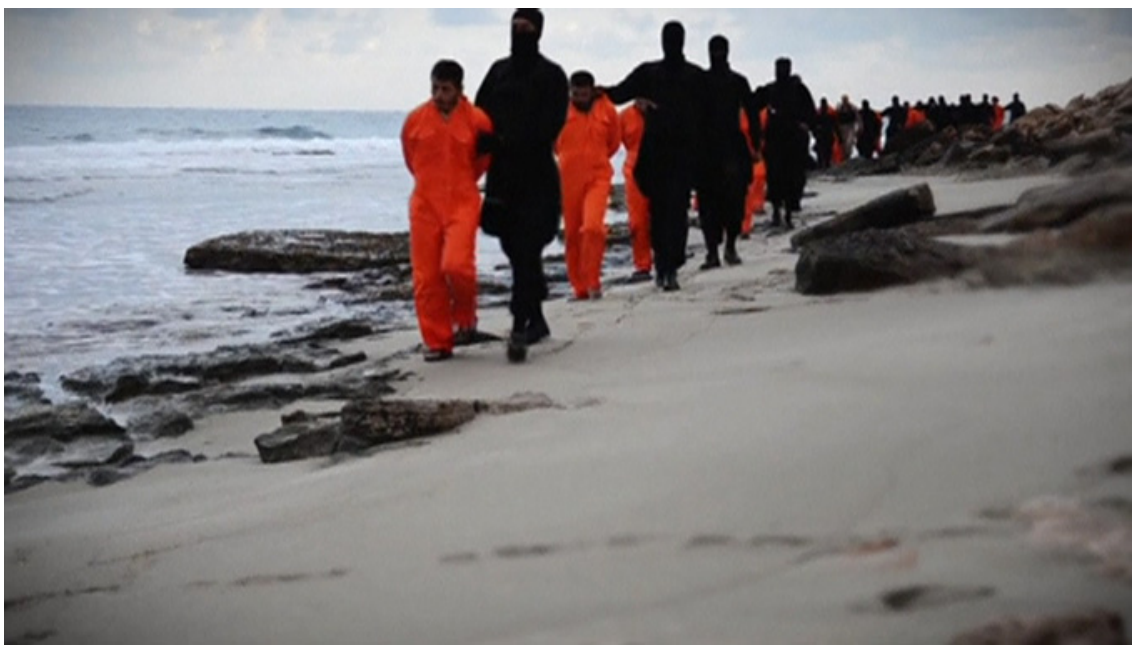

FIGURE 12 Christian victims of ISIS led to their execution on a Libyan beach SCREENSHOT FROM A YOUTUBE-VIDEO POSTED BY ISIS ON FEBRUARY 16, 2015

a strand of discussion concerning the terrorist attacks that took place in Kenya on the day of the 2015 Passion, in which Al-Shabab militants killed 147 Christians. ${ }^{42}$ The official Twitter account of The Passion linked the orange jumpsuit to religious persecution, thus connecting it with the situation in Kenya: "The Orange jumpsuit represents religious persecution. Just like in the Easter story, people today are also being persecuted and killed because of their belief". ${ }^{43}$ In this case, the persecutors were (radical) Muslims, and the victims were Christians. Responses to this tweet were varied. Whilst some people accepted the explanation that was given, others considered it to be a far-fetched excuse from the organisers of The Passion for a mistaken decision to portray Jesus this way. Some people simply contradicted the statement, saying that the orange jumpsuits were a reference to Guantanamo Bay or Isis. Several people on Twitter pointed out that these orange jumpsuits had been used in The Passion prior to their use by Is. In fact, the orange jumpsuits had already been used in the Manchester Passion, before the event took place in the Netherlands for the

42 See ввс, "Kenya Attack: 147 Dead in Garissa University Assault", April 3, 2015. https:// www.bbc.com/news/world-africa-32169080. Last accessed May 10, 2020.

43 For this tweet, including the responses to it, see The Passion (@thepassion), Twitter, April 2, 2015, https://twitter.com/thepassion/status/583724457321181184, accessed October 31, 2019. 
first time in $2011 .{ }^{44}$ Still, the negative association and moral criticism caused people to tweet comments such as: "An orange jumpsuit... I fear that not a crucifixion, but a beheading will follow". ${ }^{5}$ And: "Okay. Respect current wounds and adjust the play. Swastika=abomination, Orange Jumpsuit=abomination. Who knows [what happens] in 2016 ?"46 Producer Jacco Doornbos, on the day after the 2015 performance, explained the controversy surrounding the orange jumpsuits, arguing that the passion story was controversial in nature, just as it had been two thousand years ago. ${ }^{47} \mathrm{He}$ explained that when The Passion was first performed in the Netherlands in 2011, the orange jumpsuits were a reference to Guantanamo Bay. Now, Doornbos said, they are linked to awful videos from Is. ${ }^{48}$ Remarkably, he did not link the orange colour to religious persecution in the same way as the official Twitter account mentioned above. The organisers seem not to have collaborated with one another in order to put together a common statement on this topic.

This example led us as researchers to focus in on the (different?) attitudes of the organisers towards Islamic religion a little further. On 22 March 2016, two days before the performance of The Passion, the Islamic State shocked the general public (at least in European countries) with a series of terrorist attacks in Brussels, the capital both of Belgium and of Europe, situated about an hour's drive from the Dutch border. ${ }^{49}$ In the Netherlands, people immediately started

44 The Manchester Passion is the event that inspired the Dutch producer of The Passion to stage the passion narrative in a similar way in the Netherlands. The Manchester Passion took place on Good Friday, 14 April 2006, and was aired live оn ввс Three. For more information, see, e.g., "The Manchester Passion", ввс, April 13, 2006, http://www.bbc.co.uk/manchester/content/articles/2006/04/10/140406 _manchester_passion_event_feature.shtml. Last accessed October 31, 2019.

45 For this tweet, see Niels Roelen (@nielsroelen), Twitter, April 2, 2015, https://twitter.com/ nielsroelen/status/583716212431028225. Last accessed October 31, 2019.

46 For this tweet, see Marion (@maestraroos), Twitter, April 2, 2015, https://twitter.com/ maestraroos/status/583731689928728576. Last accessed October 31, 2019.

47 Doornbos gave this explanation at prime time on RTL Late Night, a popular talk show on RTL4, one of the largest commercial broadcasting channels in the Netherlands. Only a fragment of the TV-broadcast is available online. See RTL Late Night, "Jeroen herhaalt huzarenstukje The Passion" https://www.rtlboulevard.nl/entertainment/artikel/1253731/ video-jeroen-herhaalt-huzarenstukje-passion. Last accessed May 10, 2020.

48 It is remarkable that Doornbos used the word "vreselijk" (awful) to refer to Isis but did not use it when he talked about Guantanamo Bay.

49 The attack took place in Brussels on the morning of 22 March 2016, The Passion was performed on 24 March 2016. Is Is claimed responsibility for these attacks later on the same day. See The New York Times, "Strikes Claimed by IsIs Shut Brussels and Shake European Security", March 22, 2016, https://www.nytimes.com/2016/o3/23/world/europe/brussels -airport-explosions.html. Last accessed May 10, 2020. Prior to these attacks, Paris had 
wondering whether or not it would be safe enough to attend The Passion in the square belonging to the Dutch city of Amersfoort on the 24th. In a radio interview, a reporter asked producer Doornbos: "Have you considered cancelling the event?" He replied: "No, not for a moment; I believe that, particularly in these days, we must tell this narrative as [it is] a story of hope, a story of love and a story that connects all of us, more than that it divides".50 Now, although Islam is by no means to be equated with militant extremism, militant action and Islamic faith were, in the case of these attacks, linked together. Although the producer did not mention Islamic religion but, rather, talked about the terrorist attacks, an event based on the Christian passion narrative was presented as the complete opposite of the attacks which resulted from the radical Islamic ideology of Is (hope; love; qualities of connection vs. the sowing of division). His response was in line with the general positive framing of the passion narrative as 'a story of hope and love, ${ }^{51}$ and with the organisers' original aim to present the Christian passion narrative in the public sphere as a narrative relevant to everyone. ${ }^{52}$ However, in this particular situation, this presentation

been hit twice in 2015 (the Charli Hebdo shooting on 7 January and the Bataclan attacks on 13 November). After the suicide bombings in Brussels, more terrorist attacks in a number of other European cities followed later in the year (Nice, 14 July; several German cities in July and December 2016). Is Is claimed responsibility for most of these attacks.

Quotation taken from live radio interview with Doornbos on 24 March 2016, "The Passion 2016 in audio en video", NPO Radio 2, March 24, 2016, https://www.nporadio2.nl/nieuws/ 11261/the-passion-2016-in-audio-en-video. Last accessed May 10, 2020. The translation is mine.

$5^{1}$ In the introduction to each edition of The Passion the narrators mentioned a number of different qualities which the passion narrative embodies; love (and hope) were mentioned in the introduction to every edition.

$5^{2}$ His response was also not exceptional in the sense that there were many people who publicly expressed a strong disapproval of the attack. The Dutch Prime Minister, for example, in his official statement said that "the horrific, cowardly attacks in Brussels this morning are terrible and shocking. This is premeditated murder". See "Statement by Prime Minister Mark Rutte on the attacks in Brussels", Government of the Netherlands, March 22, 2016, https://www.government.nl/latest/news/2016/o3/22/statement-by-prime-minister -mark-rutte-on-the-attacks-in-brussels. Last accessed May 10, 2020. Later, in an interview in 2019, the producer referred to the polarisation of society and the necessity for different groups to become familiar with each other's narratives. With respect to The Passion, he seemed to have the connection between Christians and non-religious people particularly in mind, more than between Christians and people adhering to other religions: "Particularly in times of polarisation, it is important for people to be familiar with each other's narratives. In that sense, The Passion has a connecting quality, because non-religious people are watching and playing a role in the event too". "The Passion' als verbinder", Spreekbuis, April 16, 2019, https://www.spreekbuis.nl/the-passion-als-verbinder/. Last accessed May 10, 2020. 
of The Passion in the context of terrorist attacks may, perhaps inadvertently, have contributed to creating a positive frame for Christianity whilst creating a negative frame for Islam.

A year later, in an interview as part of our fieldwork, we discovered that in the preparations for the 2018 edition another organising party had strongly objected to casting a Moroccan-Dutch actor who is a practising Muslim in the role of Jesus. ${ }^{53}$ During the casting process, this actor had been offered the role of the narrator. He declined, but added that he would be eager to play the role of Jesus instead. In the ensuing discussion among the organisers, one of the Christian broadcasting companies strongly opposed having a Muslim play the character of Jesus in a Christian ritual. Although this broadcaster had consented to the presence of Muslims on camera more-generally (e.g. during the procession ${ }^{54}$ ), having the character of Jesus played by a Muslim was a bridge too far: this was an issue too sensitive for some parts of the broadcasting company's Christian constituency. Other organising bodies countered the objection with the reproach that year after year this company had agreed to the casting of atheists in the role of Jesus, despite now refusing to cast a (liberal) Muslim for this role. ${ }^{55}$ Eventually, the other organisers gave in, and a non-religious singer was allocated the role of Jesus. ${ }^{56}$

These examples reflect a level of ambiguity surrounding the meaning of religious images in contemporary Dutch society, as well as ambiguous attitudes towards Christian religion, Islamic religion and secularity more-generally (the opening quote of this chapter resonates with this ambivalence). The orange jumpsuit, in an event based on a Christian narrative in a post 9/11 context, is a multifarious symbol, the use of which can lead to moral indignation since portraying Jesus in an orange jumpsuit is believed to be undesirable in times

53 Anon., interview by $\mathrm{MK}$, autumn 2017.

54 In 2015, one of the people who was part of the procession was interviewed and told the 'journalist' that he was a Muslim and that he enjoyed The Passion. See "The Passion 2015", video, at 23:0o.

55 After they had given in, those who had been in favour of this particular actor playing the role of Jesus used the refusal of the objecting broadcaster as leverage in the negotiation of other decisions. Fieldnotes and interviews show that from the first edition in 2011 onwards, conflicts between the different interests of the organising parties, politics and (sometimes hard) bargaining have been part of the preparation process of The Passion.

$5^{6}$ In 2018, Tommy Christiaan eventually played the role of Jesus. In an interview he said: "I am not religious. But because I was in a school based on Steiner education [Vrije School, $\mathrm{MK}]$, I was raised with the Biblical stories which always contain a lot of nice themes". "Interview Tommie Christiaan als Jezus in The Passion 2018", Zin in Vandaag (кRO), March 19, 2018, https://www.televizier.nl/amusement/tommie-christiaan-a-the-passion-is-voor -iedereena. Last accessed August 19, 2019. 
of societal turmoil. Its use also leads to confusion, as it evokes references to a variety of different things, including alleged Islamic criminals, Christian victims of terrorism, and religious persecution. Presenting the Christian narrative as a story of hope and love that connects and unites rather than divides people can, in the context of terrorist attacks by Islamic State, send a message that is at odds with the inclusive aim of the event, since Muslims who dissent from the attacks do not necessarily sympathise with the Christian passion narrative, and the same holds for the inclusion and exclusion of Muslims from the event depending on their roles.

All this demonstrates that The Passion, both explicitly and implicitly, has become tied to current public debates regarding religious terrorism and violence - issues looming large both in Dutch society and in Europe more generally. A Christian play, staged in the public sphere, is not a harmless ritual, but an event that makes it clear to Dutch society that 'religion' is not as separate from identity and politics as it was previously assumed to be. The rising visibility of Islamic religion in particular, as well as radical Islamic groups whose oppression and use of violence have led to an influx of refugees into Europe, signals major change within European societies. The danger of portraying of prisoners in orange suits in The Passion is that Islam could easily come to be considered a 'bad religion', in contrast to Christianity, which is allocated the role of 'good religion'. The Passion serves to confuse ordinary everyday categories: in a secular society where religion is often considered to remain a private issue, through the performance of The Passion, the public sphere becomes a 'sacred' space ${ }^{57}$ that reflects a number of ambivalences relating to religion and secularity. In and around the performance of The Passion, Dutch society reflects and comments on itself and is enabled to realise just how far it has fallen short of its own 'ideal secular standard', in the face of (the fear of) Islamisation and the European refugee crisis that is becoming a part of daily life.

\section{The Morality of the Actors}

The third controversial issue to be considered regards the moral character of the actors. This is most clearly shown in the discussion around Dave Roelvink's portrayal of Barabbas in the 2015 edition of The Passion. Roelvink, the then twenty-year-old son of a Dutch celebrity folk singer, became famous in the Netherlands in 2014 when a sex video appeared on YouTube of an orgy in which he participated. A woman who appeared in the video brought a lawsuit

57 Sacred, according to Turner's understanding as distinct from the profane, secular, or mundane. 
against him and also accused him of theft. ${ }^{58}$ On social media, some users, especially young women, expressed that they found him very attractive. This also became clear on the square in Enschede, where we observed a small group of mothers with their young daughters: the moment Roelvink appeared on stage, the mothers lifted their daughters up so they could see him, resulting in jubilation from the daughters.

Whilst some celebrated Roelvink's appearance, some commentary focused instead on Dave's immoral background, which, in the eyes of many people, made him unsuited to participate in such an event. A poll on the website of the largest national newspaper in the Netherlands, De Telegraaf, asked people whether they thought it was acceptable that someone of disrepute (Roelvink had not yet been convicted) would participate in The Passion. Remarkably, $72 \%$ of the people who responded to the poll were against the participation of Roelvink. ${ }^{59}$ Precisely because of his background, his participation was also the focus of major discussions on social media. The character that Roelvink played was that of Barabbas, the criminal who gets released instead of Jesus. Because of his background, Roelvink was in fact typecast in this role, a point emphasised by the producer of The Passion, Doornbos. In an episode of $R T L$ Late Night that aired on the day after The Passion Doornbos explained that each year someone who has been recently discredited in the media is chosen to portray Barabbas. ${ }^{60}$ For this reason, Roelvink, in the opinion of the organisers, made an excellent candidate. ${ }^{61}$

Similar dynamics emerged in discussions about the decision to let de Groot portray Jesus. De Groot was brought up in an atheist family and had a history that included drug abuse. Before The Passion was staged, some of the

$5^{8} N U$, "Dave Roelvink vervolgd voor diefstal en heling", March 25, 2015. http://www.nu.nl/ achterklap/4018720/dave-roelvink-vervolgd-diefstal-en-heling.html. Last accessed May 10, 2020.

59 See De Telegraaf. "EO de mist in met Dave Roelvink", April 1, 2015. https://www.telegraaf .nl/entertainment/837013/eo-de-mist-in-met-dave-roelvink. Last accessed May 10, 2020. See also Mirella Klomp and Marten van der Meulen, "The Passion as ludic practice - understanding public ritual performances in late modern society: a case study from the Netherlands", Journal of Contemporary Religion 32, no. 3 (2017), 387-401. DOI: $10.1080 / 13537903.2017 .1362879$.

6o See "Jeroen herhaalt huzarenstukje", RTL Late Night.

61 The producer could have chosen to bring up a theological reason inherently related to the Christian narrative for this typecasting, stating that status reversal is the core message of the gospel (since God exalts the humble, fill the hungry with good things, etc.), but that would contradict one of the most fundamental qualities of The Passion: its openness (cf. Chapter 1). Too much theological content would hinder people's ability to ascribe their own meaning to the event. 
production team doubted whether he was suitable to play Jesus due to his background. According to the chief editors of both EO and RKK, a complicating factor in this situation was that the media focused very much on his past, instead of focusing on his upcoming performance. ${ }^{62}$ The media emphasised the conflict between de Groot's unreligious past and his participation in a religious event. Through our interviews with the organisers, it became clear that this was especially problematic for the evangelical broadcasting company EO and their supporters, since the debate did not just take place inside of different Christian groups, but was conducted publicly, primarily in the media.

The debates surrounding the actors playing Jesus and Barabbas and their characterisations in The Passion involves the public thematisation of a moral topic, i.e., whether someone of disrepute can have positive public recognition on a TV show. This is directly related to the status reversal mentioned by Turner: individuals whom one would not expect to be asked to play a role in this event, because of their way of life or their ethical behaviour, get two of the most important roles. However, that is not the whole story: just as important as this ritual reversal are the ways in which a society is able to comment on and critique itself (e.g. through social media). ${ }^{63}$ Interestingly, these comments show that, in the eyes of the public, the atheism and drug abuse of de Groot seemed to be less of a barrier to playing a role in The Passion than the sexual infractions of Roelvink. This discussion does not occur just in one location, but across a variety of different, converging media. This shows the continuing ability for religion to engender and channel public debate. ${ }^{64}$

All things considered, in dealing with the different uncertainties around national identity explored in The Passion, the striking duet of Pontius Pilate and Jesus after his arrest, which is the only song to have been a recurring element of The Passion since the very first edition, may function as an appeal to stay away from black-and-white views on (religious) matters and to refrain from radical (moral) judgements. The text of the chorus can be interpreted as underlining the complexity of current societal debates and the varying ambivalence of societal issues, thereby calling on both individuals and collectives (perhaps even upon the organisers themselves) to act in a particular way: "Don't think white, don't think black, but think in the colour of your heart".65

\footnotetext{
62 Interviews February 6, 2015 and April 13, 2015 (2) conducted by Anita Zijdemans.

63 See Turner, "Frame, Flow and Reflection", 467.

64 For further discussion, cf. Chapter 5.

65 "Denk niet zwart, denk niet wit, denk niet zwart-wit, maar in de kleur van je hart". "Zwartwit”. Frank Boeijen Groep. https://www.songteksten.nl/songteksten/14124/frank-boeijen/ zwart-wit.htm. Last accessed May 10, 2020.
} 


\section{Conclusion}

Our examination of The Passion as a public meta-social ritual has brought to light a number of different themes regarding Dutch society. In a polarising society that was thought to be secular, the portrayal both of the Jesus character, and of Christianity itself, seems to suggest that Christianity and atheism are tied to Dutch culture more than Islam is. At the same time, Christian religion and Islamic religion both carry with them a degree of ambivalence. The status reversal that can occur in public ritual has the ability to evoke moral indignation as well as a discussion of ethical conduct in which norms and values may indeed be re-shaped and calibrated. We conclude that The Passion as a public reflexive practice brings to light large-scale ambivalences regarding religion and secularity. Returning to our research question regarding the ways in which a public religious event is able to engender public reflexivity in relation to contemporary religious and moral debates we thus conclude that The Passion mirrors contemporary social issues, both through its narrative representations and depiction of different characters and in the discussions which it evokes surrounding these themes. However, it does not simply reflect contemporary issues: through its mode of performance the play also shapes the reflection, steering it in different, perhaps even divergent directions. With the use of digital media this public reflexivity also acquires a virtual dimension, as it is performed across different media which engender both interactive participation by the public over the course of the ritual and comments by the public on the ritual. These reflexive practices add to current discourses regarding (in this case) religion and secularity, and morality. This, in turn gives us reason to believe that the religious and moral debates that are engendered and channelled by The Passion may, in the long run, influence the secular selfunderstanding of the Dutch.

Three additional questions require our consideration: (1) What does The Passion tell us about the (post-)secular character of Dutch society? (2) Could a non-Christian, secular, or other-religious event have a similar role as metasocial ritual when it comes to public reflexivity? and (3) How dangerous is the potential dichotomy between good and bad religion that may have been created?

Connecting debates regarding post-secularism together with Turner's theory, it is possible to expect some kind of societal response to meta-social rituals such as The Passion, especially in times of contestation. ${ }^{66}$ The Passion

66 This does not necessarily mean that the whole of society is in accord with what is being reflected on or agrees on the outcomes of this reflection. According to Lynch, public 
shapes and evokes debates regarding important public topics. Rather than understanding this as a reversal of a trend towards secularisation, we understand it as an affirmation of the post-secular condition and the complexity and ambivalences surrounding religion and secularity in contemporary society. Without retracting our critical comments on post-secular theory (see above), we think that The Passion points to the essentially contested nature of what being 'religious' or 'secular' means in the current moment. The event derives its salience and popularity from addressing and thematising this contestation.

In elaborating this idea, the question is raised of whether a non-Christian event, either from another religion or of a secular nature, could have the same function in relation to public reflexivity. Of course, this is a topic that requires further research, but we offer a provisional argument along two diverging lines. On the one hand, it is important not to underrate the importance of the Christian heritage element in The Passion. Europeans are subconsciously shaped by their Christian past, even if they assume themselves to be secular. ${ }^{67}$ The story of the suffering Christ is so well known and taken for granted that it can form a common tableau through which to thematise and discuss important public topics in a way that a story of the life of Mohammed, to give but one example, cannot, particularly in times of religious polarisation in which some politicians use religion in both positive and negative ways to advance their own political ideologies. The narrative of the Passion and its role in European life offer the possibility for public reflexivity, so the Christian character is central. However, on the other hand, we should also be aware that there are a variety of other sacred forms, many without religious or Christian content, which offer the opportunity for society to think about itself. Non-religious events can also be experienced as sacred events and can trigger a similar type of public reflexivity as The Passion. ${ }^{68}$ So, to sum up, while the Christian character of The Passion is an important feature in our understanding of its public-reflexive role, its Christian character is by no means a necessary condition for this role.

The Passion is not a neutral event. By portraying the central characters in a particular way, the producers influence not only how the public will think

media represent "the sacred in ways that generate fragmented, overlapping and often transient forms of collective identification that may perpetuate social conflicts as much as integration". We agree with his criticism, but want to stress the collective character of the event. See Lynch, The Sacred, 88.

67 See, e.g., Jan Assmann, Religion and Cultural Memory: Ten Studies (Stanford: Stanford University Press, 2006).

68 We here pick up Lynch's distinction between the sacred and the religious, see also Chapter 4 . 
about the story but also how they will think about the moral and religious topics which are explored in the show. In this regard, we found the portrayal of Jesus and Barabbas as prisoners in orange suits particularly unfavourable, as this has the potential to reinforce a dichotomy between 'good religion' and 'bad religion'. In recent years, the orange suits have called radical Islam to mind, as something which is not part of - and, in the eyes of many, should not become part of - contemporary Dutch national identity. Radical Islam is not considered to be harmless, but is seen as a threat to both European and Dutch society. The comments and criticism evoked by the orange suits lay bare a fear of and antipathy towards radical Islam, a fear of something which is 'not our religion' and which should be kept at a great distance from society.

In this respect, it is specifically the positive characterisation of Jesus Christ as someone possessing openness and integrity, on the one hand, and the negative feelings caused by associations with religious (Islamic) fundamentalism, on the other hand, that makes the portrayal dangerous, because it may contribute to portrayals of Islam and Christianity that depict Islam as intolerant and oppressive, and Christianity as an inspiration for secular values of equality, democracy, and human rights. ${ }^{69}$ The producer and the broadcasting companies have indicated that this good-bad portrayal was not their intention, and have repeatedly indicated that they try to be inclusive. Yet, by maintaining the orange suits in a latent anti-Islamic societal climate in which the events of The Passion are characterised as liberal, open and positive they may be jeopardising their own efforts to be inclusive.

We offer our interpretation of The Passion as a meta-social ritual which engenders public reflexivity as a contribution to academic understandings of modern religion and secularity. Future research should be sensitive to the variety of sacred forms - whether they are called 'religious' or 'secular' - that people use to portray themselves, understand themselves and act upon themselves, both individually and collectively. The multimedia character of The Passion also needs to be borne in mind, reflection around and participation in contemporary rituals does not simply happen in one place, in one square,

69 This can be found in rulings by the European Court of Human Rights, but also the anti-Islamic ideology of populist politicians, like Geert Wilders in the Netherlands. Beaman, "Battles over Symbols". On the Dahlab case, see Carolyn Evans, "The 'Islamic Scarf' in the European Court of Human Rights", Melbourne Journal of International Law 7, no. 1 (2006), 52, http://www.austlii.edu.au/au/journals/MelbJIL/2006/4.html. Last accessed September 26, 2016. On the Lautsi case, see European Court of Human Rights Grand Chamber. Case of Lautsi and Others v Italy Judgement. March 18, 2011. http://hudoc.echr.coe.int/eng?i=0o1-104040. Last accessed May 10, 2020. 
in one building, but across a range of media in an ongoing process of conversation. Finally, the role of the individual and the collective in this process is also important. The Passion is an event that is both highly individualised and collectively experienced. The paradoxes, ironies, ambivalences and reversals in and around contemporary religion should alert us to the fact that interesting developments are taking place in our societies with regard to religion, and these dynamics are likely to be with us for some time. Scholars would do well to keep their eyes and ears open for other liminal forms of public reflexivity. 